Published in "Applied Clay Science doi:0.1016/j.clay.2010.09.013, 2010"

which should be cited to refer to this work.

\title{
Temperature evolution inside a pot during experimental surface (bonfire) firing
}

\author{
M. Maggetti ${ }^{\mathrm{a}, *}$, Ch. Neururer $^{\mathrm{a}}$, D. Ramseyer ${ }^{\mathrm{b}}$ \\ a Department of Geosciences, University of Fribourg, Chemin du Musée 6, CH-1700 Fribourg, Switzerland \\ ${ }^{\mathrm{b}}$ Laténium, Archaeology Museum and Institute of Prehistory, University of Neuchâtel, Espace Paul Vouga, CH-2068 Hauterive, Switzerland
}

\begin{abstract}
Time-temperature evolutions of different parts inside a pot were recorded during three experimental surface (bonfire) firings. The experimental vessels were shaped from a calcareous clay, tempered with $30 \%$ vol. of oolithic limestone. The temperature-time recording showed: (1) $T_{\max }$. was reached after 12-22 min and differed between the firings as well as inside individual vessels; (2) the range of the thermal variation within one single firing was found to be as high as $390{ }^{\circ} \mathrm{C}$, and up to $220^{\circ} \mathrm{C}$ on a specific cross-section; (3) the lowest temperature was not systematically recorded in the core of the object, as is generally expected. Under the polarizing microscope, no textural and mineralogical changes were observed in the ceramic bodies. This is sustained by powder X-ray diffraction analyses evidencing no dolomite or calcite breakdown. The presence or absence of specific illite and chlorite peaks can be generally related to $T_{\max }$. and soaking time, but equivalent firing temperature estimations do not match the measured temperatures.
\end{abstract}

\section{Introduction}

Neolithic pottery was open-fired, without any permanent kiln superstructure, either in a surface firing (bonfire), placing the dried ware directly above ground and surrounding it with fuel, or in a pit firing, placing the dried pottery in a hole in the ground and stacking the fuel around or partially below it. Additionally, the pots can be covered with sherds. In both procedures, the pottery was in direct contact with the fuel and the flames. In the first case, the retention of heat is more difficult than in the second one. Ethnographic firings give some hints on the rate of temperature increase and the length of burning. Shepard (1976) noted a rapid rise in temperature when using dung as fuel, reaching flame temperatures of $900{ }^{\circ} \mathrm{C}$ in $20 \mathrm{~min}$. She states (p. 78): "After volatile matter was burned out, as shown by the cessation of flame, the temperature continued to rise to a peak of $940{ }^{\circ} \mathrm{C}$ and then fell rapidly because the dung chips do not leave charcoal that maintains heat". This peak temperature was reached during the following $20 \mathrm{~min}$. Shepard (1976, p. 83) reports a maximum flame temperature of $962{ }^{\circ} \mathrm{C}$ with wood "stacked around pottery" for a surface bonfire firing and wrote that $1000{ }^{\circ} \mathrm{C}$ can be exceeded in a pit firing with a flue. Ethnothermometric data of Colton (1951), Lauer (1974), Shepard (1976, 1977), Irwin (1977), Nicklin (1981), Rye (1981), Pinçon (1984), Tobert (1984a,b), Woods (1984), Miller (1985), Mpika (1986), Seehy (1988), Nicholson and Patterson (1989), and Kanimba and Bellomo (1990) were summarized by Gosselain (1992). Two thirds of the flame data were in the range $300-900{ }^{\circ} \mathrm{C}$ for surface bonfires, $670-870{ }^{\circ} \mathrm{C}$ for surface firings

\footnotetext{
* Corresponding author. Tel.: +4126300 89 30; fax: +4126300 9742 . E-mail address: marino.maggetti@unifr.ch (M. Maggetti).
}

with broken ceramics covering the pottery, $620-870{ }^{\circ} \mathrm{C}$ for pit firings and $770-870{ }^{\circ} \mathrm{C}$ for pit firings with broken ceramics covering the pottery. Gosselain (1992) was the first author to study not only the evolution of the flame temperature during an ethnographic firing, but also to record the maximum gas temperature variations on the same ceramic object by placing 2-4 thermocouples directly on the inner and outer walls of the objects. He showed that within one single firing, differences vary from $94{ }^{\circ} \mathrm{C}$ to $295^{\circ} \mathrm{C}$. Such high temperature variations on a single vessel were also recorded by Nicholson and Patterson (1989) and Wotzka (1991). Livingstone Smith (2001) completed these observations based on 105 ethnographic records from Africa.

The rapid increase in temperature as well as the short firing cycle (= quick rise and cooling down of temperature) in a bonfire firing was replicated in many experiments. With sago fronds as fuel, maximum flame temperatures of $746{ }^{\circ} \mathrm{C}$ were reached after $4 \mathrm{~min}$, while the whole firing was finished after $10 \mathrm{~min}$ (Lauer 1972). Gibson and Wood (1977) recorded maximum flame temperatures of $700{ }^{\circ} \mathrm{C}$ and a firing cycle of $100 \mathrm{~min}$ for an experimental open firing done with brushwood or $800{ }^{\circ} \mathrm{C} / 100 \mathrm{~min}$ for wood as fuel. Martineau and Pétrequin (2000) placed three thermocouples directly on the walls of a single vessel and found maximum flame temperatures of 620,720 and $860{ }^{\circ} \mathrm{C}$ in the case of a bonfire and 620,760 and $800{ }^{\circ} \mathrm{C}$ or even 900 and $980{ }^{\circ} \mathrm{C}$ (experiment with two thermocouples) for a pit firing. Firings were achieved in $80 \mathrm{~min}$. Thermal profiles, heating rates, soaking times, cooling rates and the duration of firings in a pit firing with thermocouples stacked on the inside and outside walls of a pot were also reported by Sestier (2007).

These ethnographic studies and experiments gave many precise results on the thermometric evolution of flames in the pottery stack and on the surface of the walls. However, no attention was given to: (1) the 
thermometric evolution inside a pottery; (2) the textural changes of the material and (3) the mineralogical reactions in the body. In order to answer such questions, three firing experiments were conducted, placing the thermocouples in the core and the inner and outer rims of the objects and analyzing the fired specimens by optical microscopy and $\mathrm{X}$-ray diffraction.

\section{Experiments, materials and methods}

\subsection{Experiments}

The three experiments were part of the practical exercises of the one week short course Archaeometry II (Ceramics) of the Department of Geosciences, University of Fribourg, of the years 2004, 2006 and 2008. The courses took place in January or February. The firings were done in the "Village lacustre" of Gletterens, an experimental Neolithic site (Ramseyer 1997).

\subsection{Raw materials and manufacturing of the pots}

10-15 pots per experiment were shaped by coiling from a calcareous, i.e. a CaO-rich industrial clay mixture used in the brickworks of Düdingen, Switzerland (10.63 wt.\% CaO, Table 1). It belongs to the Early Miocene, Late Aquitanian (Becker et al., 2001; Becker, 2003). The mineralogical composition is given in Table 2. Becker (1996) studied very carefully the Wallenried quarry close to Düdingen and reports the following clay mineral variations between the marly layers: illite (55-78\%, mostly of polytype $2 \mathrm{M} 1$ ), Fe-chlorite (13-31\%), mixed-layer illite/montmorillonite (9-19\%, with the montmorillonite portion close to $100 \%$ ) and questionable kaolinite. The mean composition of the whole quarry is, according to Becker (2003): illite (63.3\%), chlorite (22.3\%) and smectite (14.4\%).

The mixture was tempered with crushed oolithic limestone of 1.5$3 \mathrm{~mm}$ grain size (Carlo Bernasconi AG, Zurich, Switzerland). The size and the amount of temper match the practice of Neolithic potters in Switzerland (Maggetti, 2009). Each pot was made with $1 \mathrm{~kg}$ of this industrial body (containing 17 wt.\% water to plastify the material) and $400 \mathrm{~g}$ temper. During shaping, one of these pots was wired with thermocouples. A calcareous clay shows, compared to a non-calcareous one, mineralogical changes in the firing range $800-1000{ }^{\circ} \mathrm{C}$ which can be better detected by X-ray diffraction analysis (Maggetti, 1982). Limestone was chosen in order to maximize possible mineralogical reactions at the calcareous clay-temper interface. After shaping and before firing, the objects were dried during 3 days in an electric kiln at $100{ }^{\circ} \mathrm{C}$. The dimensions of the experimental pot are given in Figs. 1,3 , and 4 . The diameter of the cross-sections were $15 \mathrm{~mm}$ for thermocouples 1-3 and thermocouple 4,11 mm for thermocouple 7 in the experimental pot in 2004, $8 \mathrm{~mm}$ for thermocouple 1 and $15 \mathrm{~mm}$ for

Table 1

Chemical composition of the industrial marly body from the brickworks of Düdingen (Switzerland), dried at $110{ }^{\circ} \mathrm{C}$

\begin{tabular}{lrlr}
\hline Oxide & wt.\% & Element & ppm \\
\hline $\mathrm{SiO2}$ & 50.74 & $\mathrm{Ba}$ & 422 \\
$\mathrm{TiO2}$ & 0.64 & $\mathrm{Cr}$ & 78 \\
$\mathrm{Al2O3}$ & 14.69 & $\mathrm{Cu}$ & 27 \\
$\mathrm{Fe} 2 \mathrm{O} 3$ & 2.92 & $\mathrm{Ga}$ & 10 \\
$\mathrm{FeO}$ & 1.95 & $\mathrm{Nb}$ & 8 \\
$\mathrm{MnO}$ & 0.08 & $\mathrm{Ni}$ & 55 \\
$\mathrm{MgO}$ & $\mathrm{Pb}$ & 1 \\
$\mathrm{CaO}$ & $\mathrm{Rb}$ & 112 \\
$\mathrm{Na2O}$ & 10.69 & $\mathrm{Sr}$ & 347 \\
$\mathrm{~K} 2 \mathrm{O}$ & $\mathrm{Th}$ & 6 \\
$\mathrm{P} 2 \mathrm{O} 5$ & 0.83 & $\mathrm{~V}$ & 105 \\
$\mathrm{H} 2 \mathrm{O}+$ & 2.77 & $\mathrm{Y}$ & 21 \\
$\mathrm{CO} 2$ & 0.10 & $\mathrm{Zn}$ & 81 \\
$\mathrm{Total}$ & 3.92 & $\mathrm{Zr}$ & 124 \\
\hline
\end{tabular}

Table 2

Mineralogical composition of the industrial marly body.

\begin{tabular}{lrlr}
\hline Mineral & wt.\% & Clay minerals & wt.\% \\
\hline Quartz & 25 & Illite & 45 \\
Kalifeldspar & 10 & Smectite & 30 \\
Plagioclase & 10 & Chlorite & 15 \\
Calcite & 15 & Kaolinite & 10 \\
Dolomite & 5 & Total & 100 \\
Clay minerals & 35 & & \\
Total & 100 & & \\
\hline
\end{tabular}

thermocouples $3-5$ in $2006,10 \mathrm{~mm}$ for thermocouple $1,12 \mathrm{~mm}$ for thermocouple 2 and $15 \mathrm{~mm}$ for thermocouple 4 in 2008.

\subsection{Temperature record}

Four to seven thermocouples type $\mathrm{K}(\mathrm{Ni} / \mathrm{NiCr})$ were put in direct contact on the outside and the inside surface of the chosen pot and "glued" with a small lump of clay (1-2 mm thick), as well as in the core, along one or two cross-sections throughout the object (Figs. 1, 3, and 4). Except in experiment 2006, at least one thermocouple measured the gas temperature outside the vessel. Range of the thermocouples was -50 to $+1200^{\circ} \mathrm{C}$. Temperatures were recorded online on a PC.

\subsection{Fuel}

For the 2004 and 2006 experiments, dry fuel, i.e. dead fine branches (diameter $<3 \mathrm{~cm}$ ) and more thicker wood pieces (diameter $10-3 \mathrm{~cm}$ ) of differing tree species, mostly alder (Alnus) and hazel (Corylus) from the forest surrounding the Neolithic village were chosen, without any previous drying if superficially wet. In the 2008 experiment, commercially available wooden sticks of Beech tree (Fagus) were used (dimensions $30 \mathrm{~cm}$ long, $9 \mathrm{~cm}$ diameter).

\subsection{Firing}

The $10-15$ pots were put on one level, without stacking, on the floor of a "Neolithic" house, with the wired test specimen in the center. In the 2004 and 2006 experiments, the test specimen was in an upright, in the 2008 experiment in a downright position. The whole set was then covered with straw and wooden fuel. Some fuel was added during firing when the flames were dying out. After firing, the test pots weighted $1.2 \mathrm{~kg}$.

\subsection{Microscopy}

Thin sections were made across the bodies of the experimental vessels where the thermocouples were placed and studied under a polarizing microscope.

\subsection{Chemical analysis}

For the chemical analysis by X-ray fluorescence (XRF), $20 \mathrm{~g}$ of the industrial body were dried at $110{ }^{\circ} \mathrm{C}$ and ground to a fine powder in a tungsten carbide mill. Determination of major ( $\mathrm{Si}, \mathrm{Ti}, \mathrm{Al}, \mathrm{Fe}, \mathrm{Mn}, \mathrm{Mg}, \mathrm{Ca}$, $\mathrm{Na}, \mathrm{K}$, and P) and trace elements ( $\mathrm{Ba}, \mathrm{Cr}, \mathrm{Cu}, \mathrm{Ga}, \mathrm{Nb}, \mathrm{Ni}, \mathrm{Pb}, \mathrm{Rb}, \mathrm{Sr}, \mathrm{Th}, \mathrm{V}, \mathrm{Y}$, $\mathrm{Zn}$, and $\mathrm{Zr}$ ) was performed. A circular tablet ( $40 \mathrm{~mm}$ diameter) of glassy material (calcined powder) was used for the major elements. A circular tablet of pressed powder (non-calcined) was used for the trace elements. The preparation of the glass tablet occurred as follows: after calcination of the powdered sample for $1 \mathrm{~h}$ at $1000^{\circ} \mathrm{C}, 1.2 \mathrm{~g}$ of this calcined material was mixed with $5.7 \mathrm{~g}$ of lithium-tetraborate and $0.3 \mathrm{~g}$ of lithium-fluoride. This mixture was then placed in a Pt-Au crucible and melted at $1150{ }^{\circ} \mathrm{C}$ before being poured into a preheated mould and cooled with compressed air. The preparation of the pressed tablet was done as follows: $2.5-3.0 \mathrm{~g}$ of initial powder was mixed with 

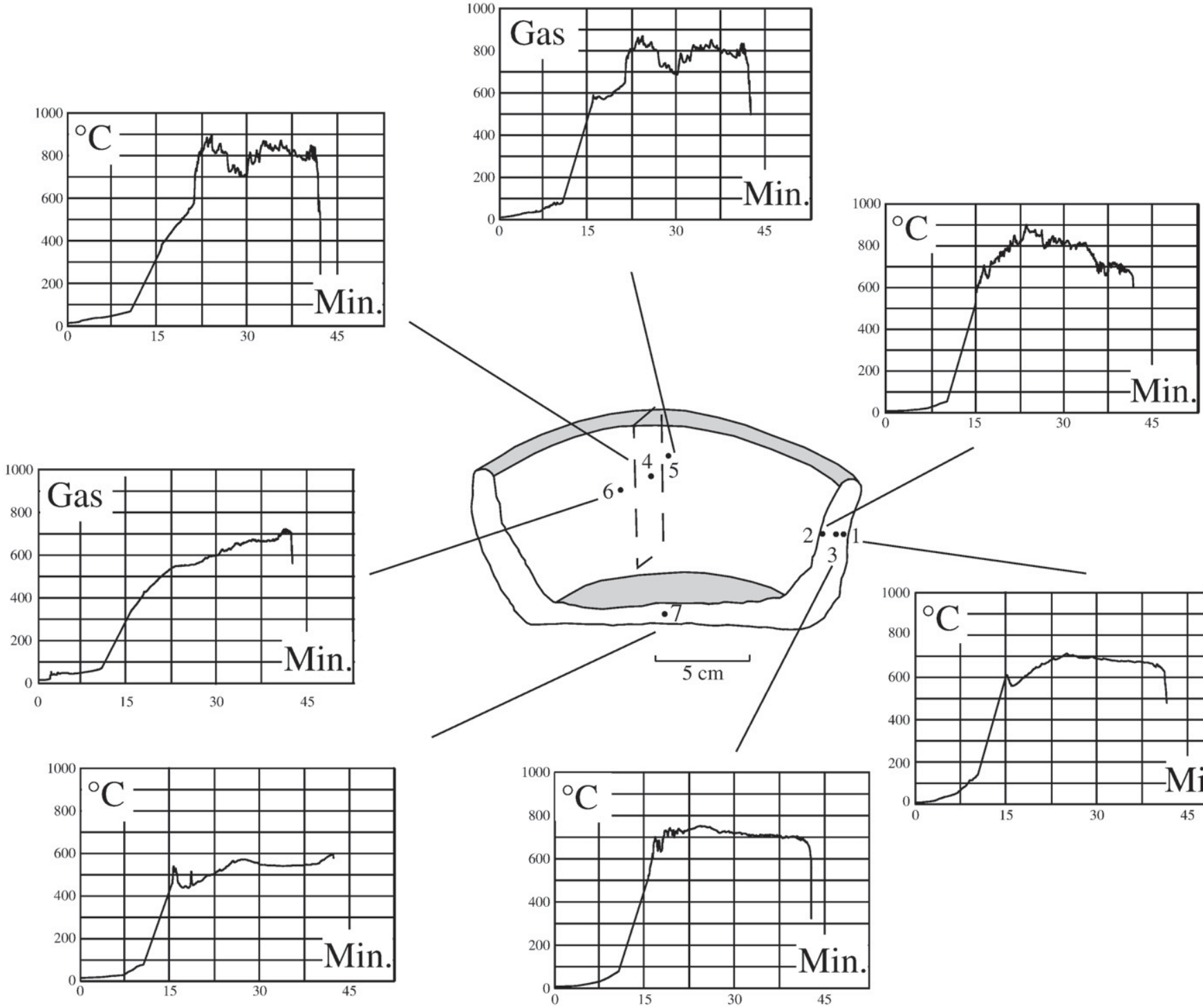

Fig. 1. Time-temperature curves of the 2004 experiment

approximately $0.3 \mathrm{ml}$ of a moviol saturated aqueous solution. This was then added to a $32 \mathrm{~mm}$ mould and subjected to 6 tons for at least $1 \mathrm{~min}$ The tablet was carefully removed and placed on a bed of $7 \mathrm{~g}$ of boric acid in a $40 \mathrm{~mm}$ mould. This was again subjected to 6 tons for at least $1 \mathrm{~min}$. The resulting tablet was dried in a vacuum for $24 \mathrm{~h}$ at room temperature. Analytical measurements were performed using a Philips PW 1400 $\mathrm{X}$-ray spectrometer with $\mathrm{Cr}$ anticathode. The conversion of the measured values to weight percentage concentrations utilized standardization curves established on reference samples (e.g. USGS, NIM, and ANRT). The results of the measurements of the major elements of the matrix were corrected with Philips alpha coefficients.

The FeO content was determined using the 2.2 dipyridilic method (Lange and Vejdelek, 1980) and a Philips Pye-Unicam PU 8650 at $528 \mathrm{~nm}$.

\subsection{X-ray diffraction analysis}

Mineral analyses of the raw industrial clay body (same powder as for the chemical analysis) were performed by X-ray diffraction (XRD) using $\mathrm{CuK}_{\alpha}$ radiation $(30 \mathrm{kV}, 40 \mathrm{~mA})$ on a Philips PW 1800, in the range $0-65^{\circ} 2$ Theta. A semi-quantitative analysis of the $<2 \mu \mathrm{m}$ size fraction of the clay was obtained by multiplying the intensities of the basal reflections of each clay mineral by suitable factors according to unpublished internal reports of the Institute of Mineralogy and Petrography of the University of Bern (Switzerland). Reproducibility and error are $\pm 5 \%$ and $\sim 20 \%$, respectively.

$0.9 \mathrm{~g}$ of the fired clay surrounding the thermocouples was gently crushed and sieved through a mesh $<0.125 \mathrm{~mm}$ in order to eliminate mostly all coarse temper particles. The subsequent XRD mineral analysis was performed with the same procedure as for the industrial clay body.

\section{Results}

\subsection{Firing experiments}

Time-temperature curves for the three experiments are given in Figs. 1-4. Maximum temperature and soaking time are summarized in Table 3.

In 2004, the objects were laid on the dry, clayey floor of the "Neolithic" house, the fuel was lit from above and it took more than 7 min to show an effect in the walls and cores of the object (Fig. 1). The rate of temperature increase was rapid and maximum temperatures were reached 17 to $22 \mathrm{~min}$ after setting fire. The experimental pot was removed from the firing area after $37 \mathrm{~min}$. For a given time, 


\section{a}

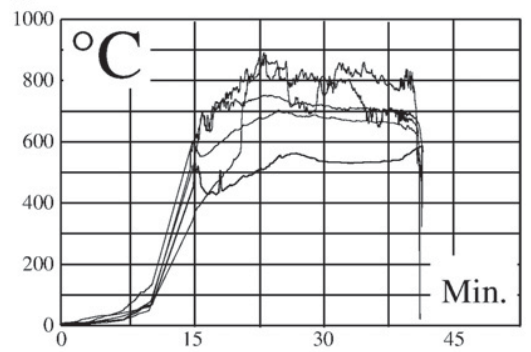

b

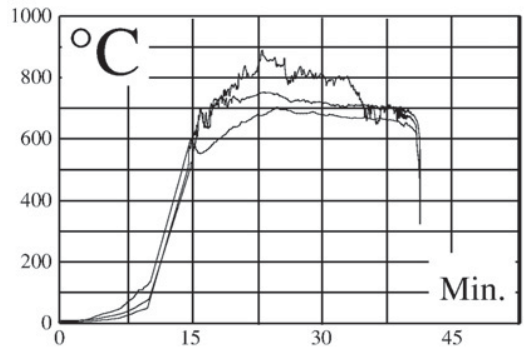

c

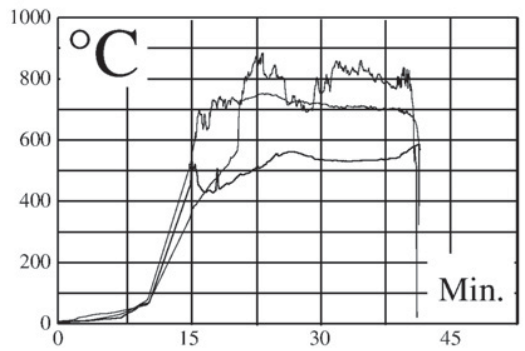

Fig. 2. Time-temperature curves of the 2004 experiment; (a) evolution of all thermocouples inside the pot, (b) evolution in transects 1-3, and (c) evolution of the three cores.

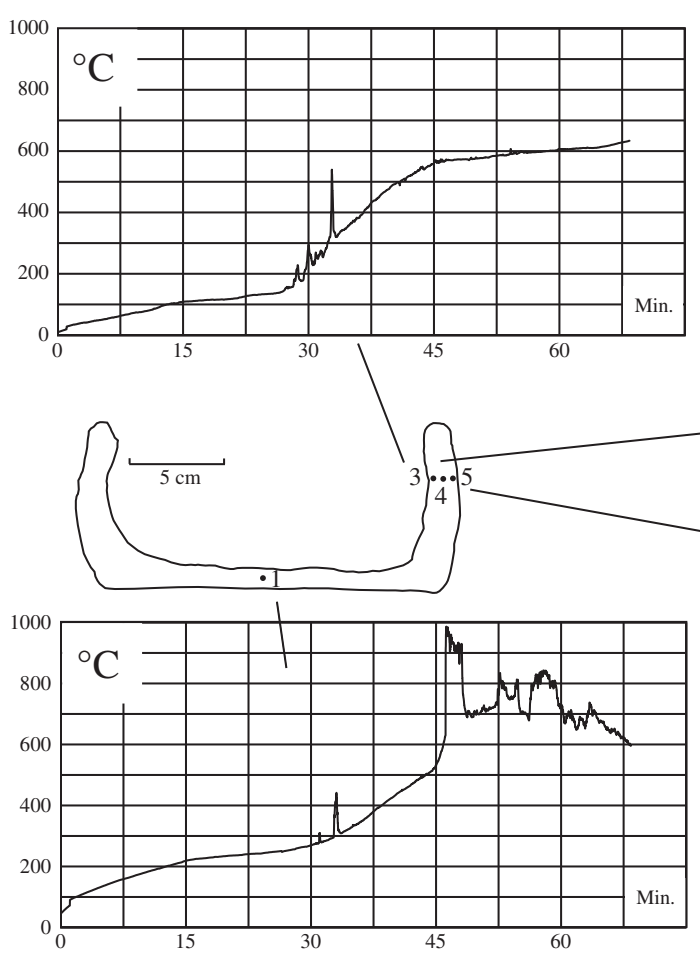

differences as high as $390{ }^{\circ} \mathrm{C}$ were measured between the single thermocouples (Fig. 2a).

In transects $1-3$, maximum temperatures of $707^{\circ} \mathrm{C}$ were measured in the external wall (thermocouple 1 ), $893^{\circ} \mathrm{C}$ in the internal wall (thermocouple 2), and $751^{\circ} \mathrm{C}$ in the core of the vessel (thermocouple 3 ). In this transect, maximum differences of about $220^{\circ} \mathrm{C}$ were recorded for a given time (Fig. 2b). The time-temperature evolution of transects 4-6 is very similar for thermocouples 4 (core) and 5 (gas), with maximum temperatures in the range $870-895^{\circ} \mathrm{C}$. Thermocouple 4 and the external gas thermocouple 5 record a drop of temperature after a first temperature maximum. A second temperature peak was reached after adding some fuel. This behavior is not evidenced by the gas thermocouple $6\left(T_{\max } .716^{\circ} \mathrm{C}\right)$. Thermocouple 7 records, as expected, the lowest maximum temperature $\left(582^{\circ} \mathrm{C}\right)$, since the pot was placed directly on the cold clayey floor, without any heating from below. The three cores showed, for a given time, temperature differences of as high as $380^{\circ} \mathrm{C}$ (Fig. 2c).

In the 2006 firing, straw and small wood chips were first laid on the ground and ignited, before the pottery was all placed on the firing area in order to preheat it during a laps of time. This explains the slow rate of heat increase in the first $28 \mathrm{~min}$ (Fig. 3). When the fire was set on top of the fuel stack, maximum temperatures were reached in 7-15 min. Astonishingly, the bottom thermocouple 1 recorded, after some minutes, $T_{\max }$. close to $980^{\circ} \mathrm{C}$, most probably induced by fallen charcoal, whereas in transects 3-5 both walls showed maximum temperatures well below the $813^{\circ} \mathrm{C}$ of the core. Marked temperature variations are visible and due to the adding of fuel. The recording was stopped after $67 \mathrm{~min}$.

The distribution of temperatures in the three core thermocouples of experiment 2008 is very similar (Fig. 4). The pottery was placed upside down on an ash bed of freshly burned straw and wooden chips, thereupon covered with fuel. After $7 \mathrm{~min}$ in this preheating position, fuel was ignited. Temperatures of $700{ }^{\circ} \mathrm{C}$ and more were reached in 7 to 10 min in the measured central parts of the pot, with close-to-maximum temperatures of 771 to $804^{\circ} \mathrm{C}$. Time-temperature evolution of gas (thermocouple 3 ) and the adjacent core (thermocouple 2) are similar. Comparing to 2004 and 2006, high temperatures were maintained

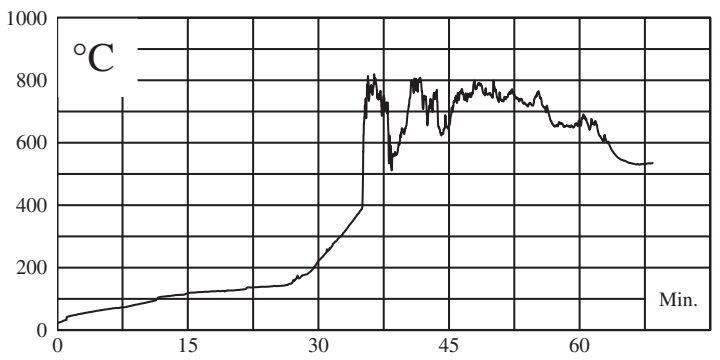

Fig. 3. Time-temperature curves of the 2006 experiment. 

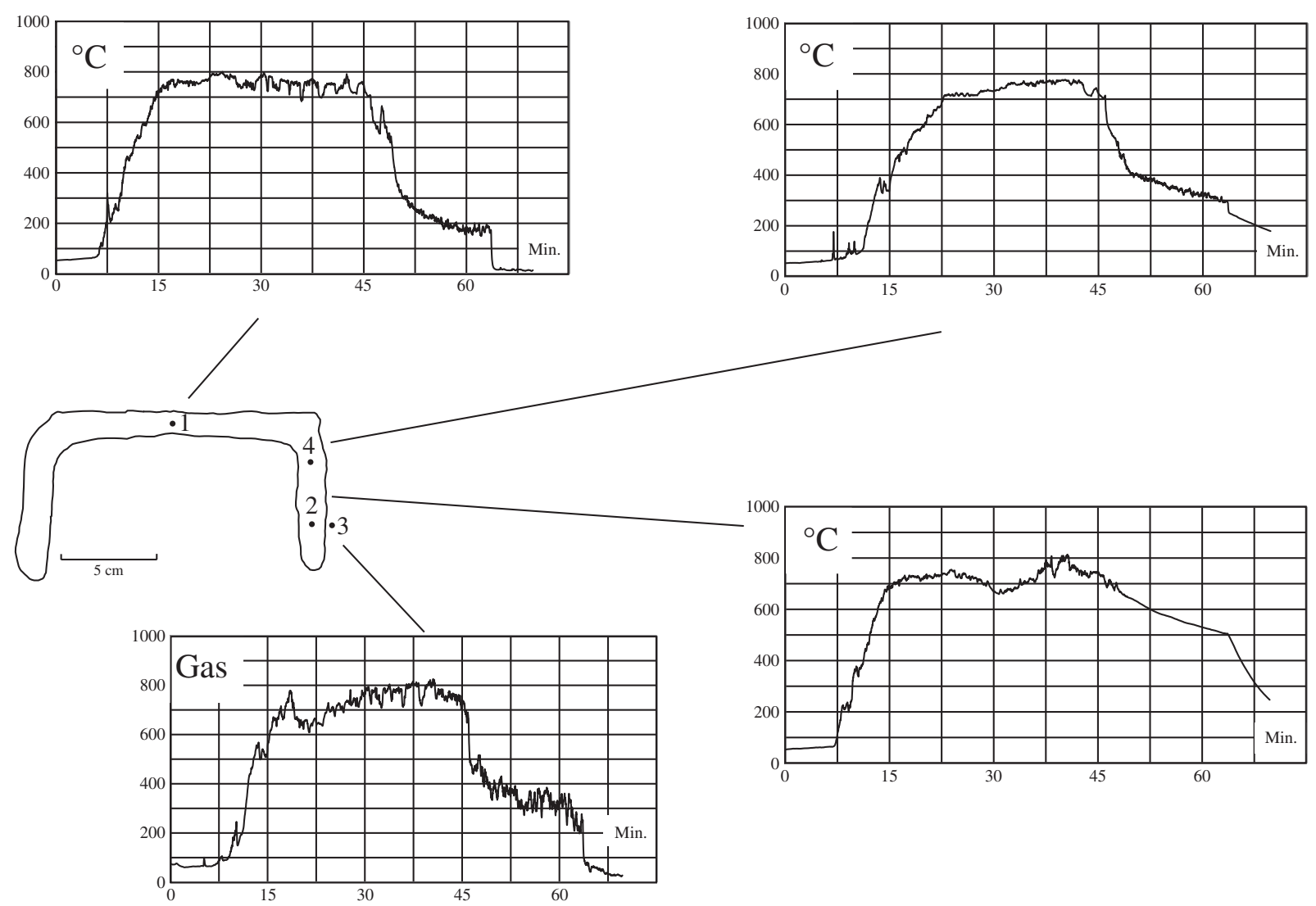

Fig. 4. Time-temperature curves of the 2008 experiment.

much longer. This difference is mainly due to the use of Beech wood, which burned slowly, compared to the local fuel of the 2004 and 2006 experiments.

After firing, the three experimental vessels had a reddish surface color. Charcoal and ash which fall during firing inside the pots gave a grey to black surface color. In all cross-sections, a very thin reddish rim of 1-2 mm appears surrounding an extensive black or grey core, as commonly seen in Neolithic pottery.

\subsection{Textural changes}

Under the microscope, neither textural nor mineralogical changes were observed (Fig. 5a). The matrix is anisotropic and rich in tiny, primary calcites. Further, no reaction zone is visible at the contact of the oolithic limestone with the matrix, even for such cases as thermocouple $2004 / 2$, where temperatures of more than $800^{\circ} \mathrm{C}$ were maintained during $10 \mathrm{~min}$ (Fig. 5b). Seemingly, these temperatures were not high enough to cause incipient dissociation of the calcites, resulting in lime spalling effects during post-firing rehydration of the $\mathrm{CaO}$ grains.

\subsection{Mineralogical changes}

Sieved samples from the matrix around the thermocouples show, as evidenced by X-ray analysis, the presence of quartz + plagioclase + kalifeldspar + calcite + dolomite + illite $+/-$ chlorite. Smectite and

Table 3

Thermal profile (maximum temperature and soaking time) and phase associations of the samples.

\begin{tabular}{|c|c|c|c|c|c|c|c|c|}
\hline \multirow[t]{2}{*}{ No. } & \multirow{2}{*}{$\begin{array}{l}\text { Location of the } \\
\text { thermocouples }\end{array}$} & \multirow{2}{*}{$\begin{array}{l}\text { Max. temperature } \\
\left({ }^{\circ} \mathrm{C}\right)\end{array}$} & \multicolumn{5}{|c|}{ Soaking time (min) } & \multirow{2}{*}{$\begin{array}{l}\text { Phase } \\
\text { association }\end{array}$} \\
\hline & & & $>700{ }^{\circ} \mathrm{C}$ & $>750$ & $>800$ & $>850$ & $>900$ & \\
\hline $2004 / 1$ & External wall & 707 & 5 & 0 & 0 & 0 & 0 & $\mathrm{~b}$ \\
\hline $2004 / 2$ & Internal wall & 893 & 22 & 16 & 10 & 3 & 0 & b \\
\hline $2004 / 3$ & Core of the wall & 751 & 21 & 2 & 0 & 0 & 0 & $\mathrm{~b}$ \\
\hline $2004 / 4$ & Core of the wall & 895 & 23 & 19 & 11 & 4 & 0 & $\mathrm{~b}$ \\
\hline $2004 / 5$ & Gas outside & 869 & & & & & & \\
\hline $2004 / 6$ & Gas outside & 716 & & & & & & \\
\hline $2004 / 7$ & Core in the bottom & 582 & 0 & 0 & 0 & 0 & 0 & a \\
\hline $2006 / 1$ & Core in the bottom & 981 & 18 & 12 & 7 & 4 & 4 & a \\
\hline $2006 / 3$ & Internal wall & 633 & 0 & 0 & 0 & 0 & 0 & a \\
\hline $2006 / 4$ & Core of the wall & 813 & 18 & 16 & 4 & 0 & 0 & $\mathrm{~b}$ \\
\hline $2006 / 5$ & External wall & 682 & 0 & 0 & 0 & 0 & 0 & $\mathrm{a}$ \\
\hline 2008/1 & Core in the bottom & 799 & 30 & 15 & 0 & 0 & 0 & c \\
\hline $2008 / 2$ & Core of the wall & 804 & 29 & 8 & 4 & 0 & 0 & c \\
\hline $2008 / 3$ & Gas outside & 817 & & & & & & \\
\hline $2008 / 4$ & Core of the wall & 771 & 24 & 7 & 0 & 0 & 0 & a \\
\hline
\end{tabular}



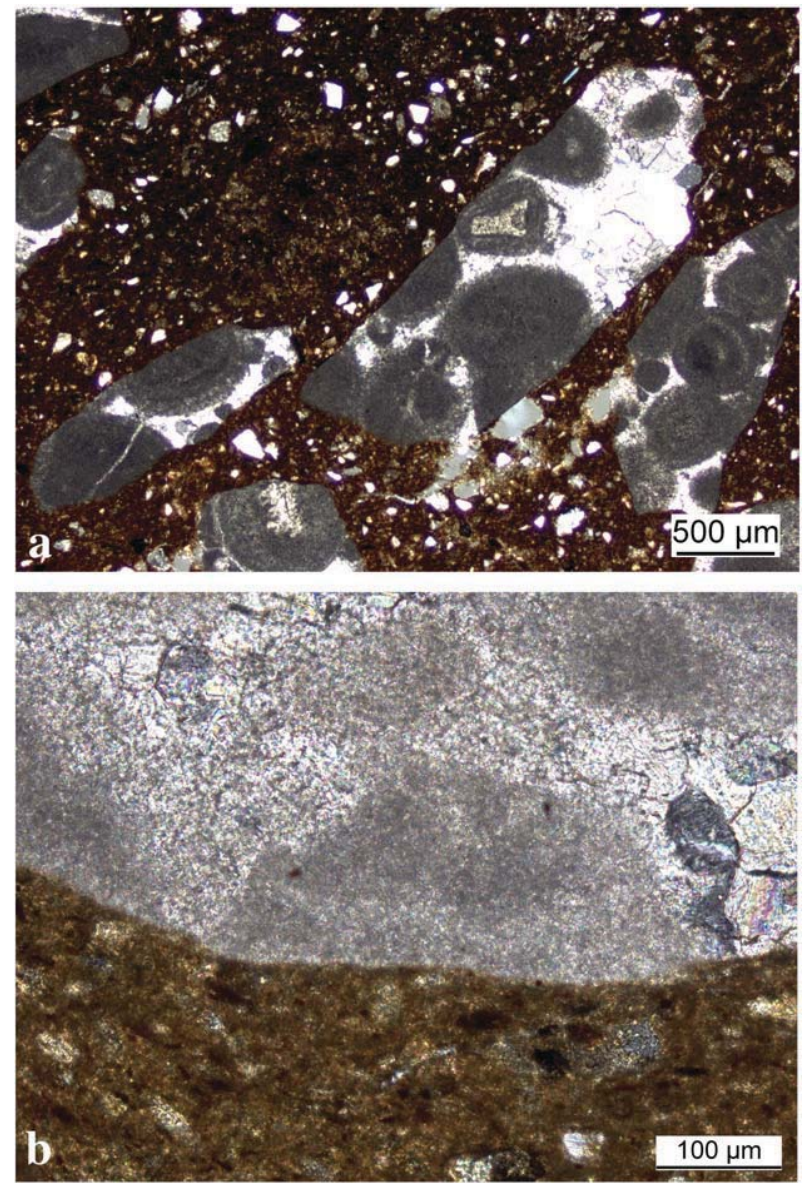

Fig. 5. Thin-section photomicrographs of experimental pottery (cross polarized light). (a) Temper of oolithic limestone set in a fine grained, calcareous matrix (area surrounding the thermocouple 2006/4). (b) Contact between the oolithic limestone (above) and the matrix (below), with no evidence of a mineralogical reaction (area of thermocouple 2004/2).

kaolinite of the raw body (Table 2) and possibly newly formed Ca-silicates could not be detected. Hematite is present in the reddish samples 2004/7, $2006 / 1$ and 2006/3. All specimens can be classified into three phyllosilicate groups respectively phase associations (Table 3; Fig. 6):

(a) Illite $(001,002,110)+$ chlorite: samples 2004/7, 2006/1, 2006/ $3,2006 / 5,2008 / 4$

(b) Illite $(002,110)+$ chlorite: samples $2004 / 1-4,2006 / 4$

(c) Illite $(002,110)$ : samples 2008/1, 2008/2.

There is a weak relationship between the phyllosilicate groups, $T_{\text {max. }}$ and the soaking time $>700{ }^{\circ} \mathrm{C}$ (Table 3). Group (a) enclose three samples fired below $700{ }^{\circ} \mathrm{C}$ - with the exceptions of 2006/1 and $2008 / 4$, group (b) four samples with soaking times $>700{ }^{\circ} \mathrm{C}$ of $18-$ 23 min - with the exception of 2004/1, and group (c) samples with soaking times $>700{ }^{\circ} \mathrm{C}$ of $29-30 \mathrm{~min}$.

\section{Discussion}

\subsection{Time-temperature evolution in the experimental pots}

Time-temperature measurements in the walls and the cores of the experimental pots confirmed the results of previous experimental and ethnographic flame or gas measurements during open firing: (a) the dimensions of the firewood (small branches or bigger, commercially available sticks) have no or only little effect on $T_{\max }$ and the heating rate; (b) open firings are characterized by fast heating rates, as 35-75$115^{\circ} \mathrm{C} /$ min were recorded; (c) maximum temperatures in a single pot

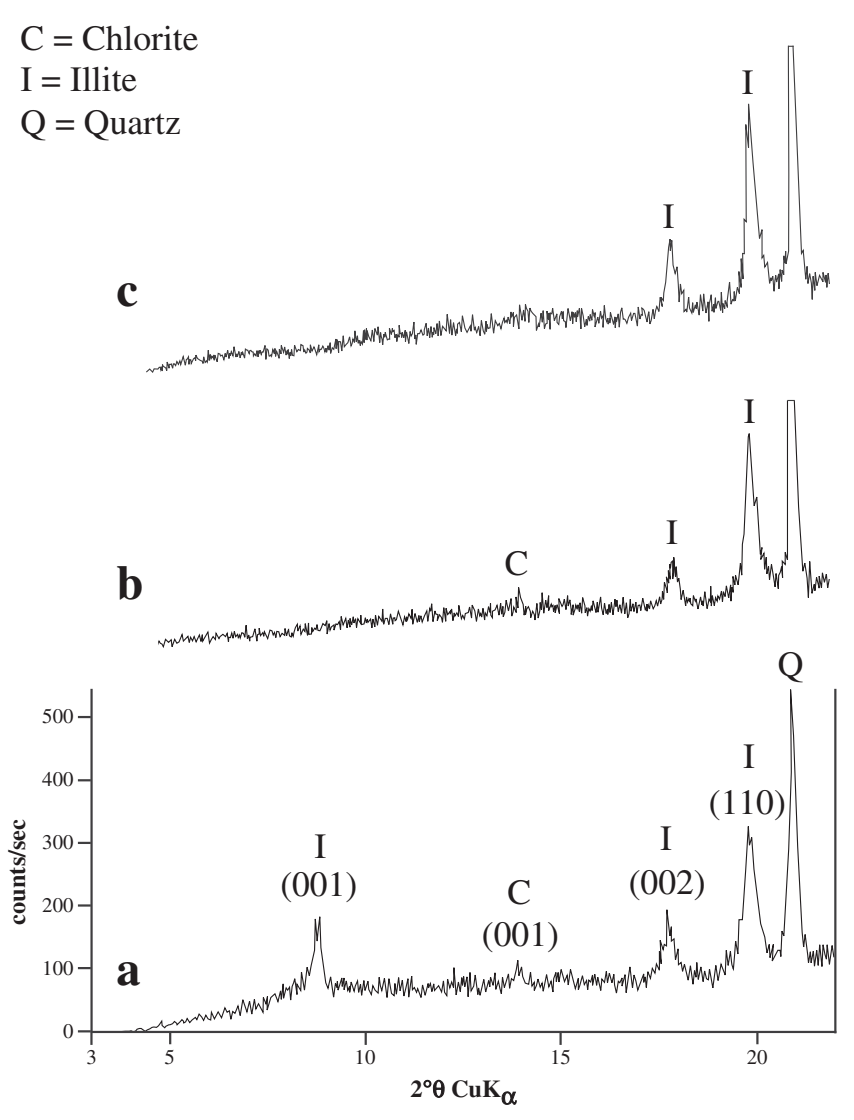

Fig. 6. X-ray diffraction patterns of the phyllosilicate groups (a), (b) and (c).

and between different firings are extremely variable. In the 2004 experiment, differences up to $390^{\circ} \mathrm{C}$ were measured; (d) maximum temperatures can reach $800-900^{\circ} \mathrm{C}$; (e) a pot can be ceramised in $10-$ $20 \mathrm{~min}$; and (f) gas measurements close to a single pottery can record important temperature variations, up to $200^{\circ} \mathrm{C}$.

The experiments showed further that gas temperatures can be higher (Experiment 2008) or lower (in 2004) than the temperature inside a pot on the same transect. Identification of a gas temperature from outside a pot may therefore not be representative for the body's temperature close to this gas. On the other hand, very similar timetemperature evolutions of gas and pottery were recorded in the 2004 and the 2006 experiments. Seemingly, the fine grained matrix of the highly porous vessels, where hot gas could circulate very rapidly, was quickly heated and equilibrated with the surrounding gas. On the other hand, it cannot be excluded that some thermocouples measured the temperature of the gas in the pores and not of the solid matter.

\subsection{Redox conditions}

In a manganese poor clay, black and grey colors can be caused by carbon or Fe-rich spinels such as magnetite or hercynite. These pigments were not detected with XRD analysis. On the other hand, it is well known that the organic matter inside a clay body is transformed to carbon during firing. The ceramic object is then black or grey, as long as carbon is present. If enough oxygen is available, carbon oxidizes to $\mathrm{CO}_{2}$, and the body turns to red due to the presence of hematite. The atmosphere inside the pottery, i.e. in the now black and grey cores, was therefore mostly reducing during the whole firing cycle, since carbon was stable. However, at the end of the firing, when the fuel has burned down, oxygen could enter the body and oxidize the carbon particles in the rims, giving reddish colors. 


\subsection{Suitability of calcareous raw materials (marls and temper) in open firings}

Calcareous clays (marls) and calcareous non-plastic inclusions (e.g. limestones) are believed to be dangerous materials in open firings. Under oxidizing conditions, calcite $\mathrm{CaCO}_{3}$ decomposes to lime $\mathrm{CaO}$ at temperatures starting near $600-700{ }^{\circ} \mathrm{C}$ (Rye, 1976; Letsch and Noll, 1983). Subsequent hydration of the $\mathrm{CaO}$ particles to Portlandite $\mathrm{Ca}(\mathrm{OH})_{2}$ causes lime spalling, resulting eventually in the complete destruction of the pot. In Switzerland, a survey of the raw materials employed by Neolithic potters showed the predominant use of silicate clays and temper (Maggetti, 2009). Other Neolithic potters did not fear CaO-rich clays and temper for ceramic production, as evidenced by Middle and Late Neolithic pottery from France and Italy (e.g. Basso et al., 2006; Laviano and Muntoni, 2006; Martineau et al., 2007). The incipient dissociation of calcite during firing depends mainly on $\mathrm{fO}_{2}$, as it can be increased from $600{ }^{\circ} \mathrm{C}$ (oxidizing conditions, $\mathrm{fO}_{2}=0.2 \mathrm{~atm}$ ) to $800{ }^{\circ} \mathrm{C}$ (reducing conditions, temperature dependant Boudouard equilibrium), see Letsch and Noll (1983). However, in Maritan's (2004) experiments, calcite was stable up to $850{ }^{\circ} \mathrm{C}$ for both oxidizing and reducing firings, whereas Maritan et al. (2006) found only smaller differences between the upper stability of calcite under oxidizing $\left(800{ }^{\circ} \mathrm{C}\right)$ and reducing $\left(850^{\circ} \mathrm{C}\right.$ ) firing conditions. Reducing conditions prevail in a pottery during firing, as long as the initially present organic matter is not oxidized. This was the case in the now black or greyish cores of the three experimental firings and explains the post-firing physical stability of these vessels. No lime spalling appeared - even the 2004 experimental vessel showed no weakness after a 5 year exposition to room humidity - confirming the statement of Fabbri et al. (2002) that pit firing in a semi-reducing condition “.... allows temperatures to rise as high as $800{ }^{\circ} \mathrm{C}$ without promoting calcite decomposition and subsequent decohesion of the artefacts as in oxidizing environment".

\subsection{Archaeometric implications}

It is common practice to estimate the firing temperature of archaeological sherds, i.e. the so-called equivalent firing temperature EFT, (Tite, 1969), with several physical methods (Heimann, 1976; Heimann and Franklin, 1980; Heimann, 1982, 1989; Tite, 1995, Mirti, 1998). Many of them use a clay with a similar chemical and mineralogical composition as the studied ceramic. This raw material is fired under controlled conditions (maximum temperature, heating rate, soaking time, and firing atmosphere), then analyzed with the chosen method and the results were compared with those of the pottery. Such an approach can be valid for a kiln firing in an oxidizing atmosphere, where the thermal characteristics of ancient and modern firings may be more or less equivalent, but not for an open firing where no direct control of all firing parameters is possible. A popular method among archaeometrists is X-ray diffraction analysis, which tracks the heat related mineral changes in a given clay. The atmosphere inside the experimental pots was, as explained in the previous chapter, reducing. Therefore, experimental firings of a calcareous clay under reducing conditions (Heimann et al., 1980; Letsch and Noll, 1983; Maniatis et al., 1983; Pradell et al., 1995; Maritan, 2004; Maritan et al., 2006) must be used. In Heimann et al.'s experiment (CaO 7.0 wt.\%), illite and calcite break down between 850 and $966{ }^{\circ} \mathrm{C}$ under strong reducing conditions $\left(\mathrm{fO}_{2}<10^{-4} \mathrm{~atm}\right.$ ) and $820-940^{\circ} \mathrm{C}$ under less reducing conditions $\left(\mathrm{fO}_{2}>10^{-4} \mathrm{~atm}\right)$. In Letsch and Noll's experiment ( $\mathrm{CaO}$ 14.0 wt.\%), illite and calcite break down $>800{ }^{\circ} \mathrm{C}$ and are no longer detectable at $900{ }^{\circ} \mathrm{C}$. In Maniatis et al.'s experiment (calcite $30 \mathrm{wt} . \%$ ), firing at $700{ }^{\circ} \mathrm{C}$ resulted in the decomposition of chlorite. At $900{ }^{\circ} \mathrm{C}$, all illite and calcite disappeared. Pradell et al. studied the stability of iron-bearing phases, but gave no clues to the behavior of calcite under reducing conditions. In Maritan's three-clay experiments ( $\mathrm{CaO}$ 5-10 wt.\%), calcite and illite are stable up to $850{ }^{\circ} \mathrm{C}$, dolomite to $750{ }^{\circ} \mathrm{C}$, chlorite (001) to $500{ }^{\circ} \mathrm{C}$ and chlorite (002) to $650^{\circ} \mathrm{C}$. By contrast, in Maritan et al.'s experiment ( $\mathrm{CaO} 7.7 \mathrm{wt} . \%$ ), decomposition of chlorite begins at $500{ }^{\circ} \mathrm{C}$ with the disappearance of the (002) reflection. At $650{ }^{\circ} \mathrm{C}$, the (001) reflection was gone. Illite could not be detected above $800{ }^{\circ} \mathrm{C}$ and calcite was stable up to $850^{\circ} \mathrm{C}$. Based on these results, max. EFT's of $700{ }^{\circ} \mathrm{C}$ can be inferred for the phyllosilicate groups (a) and (b), since chlorite is present. However, six of ten samples of these groups recorded $T_{\max }$. much higher than $700{ }^{\circ} \mathrm{C}$. Neglecting chlorite and based on the stability of illite and calcite, $800-850{ }^{\circ} \mathrm{C}$ could be inferred for the 2004-2008 firings, since both minerals are present in all samples. But this agrees with only three "real" $T_{\text {max.; }}$; six are lower and three higher. The latter was recorded for few minute soaking times exceeding $850^{\circ} \mathrm{C}$. Such a short lapse of time was seemingly not long enough to affect the stability of illite and calcite. This could be a factor explaining the absence of any textural or mineralogical reaction in the matrix and at the contact matrix/calcareous temper even in these samples.

EFT's for the reddish specimens 2004/7, 2006/1 and 2006/3 can be inferred from the mineralogical evolution of a calcareous clay under oxidizing firing, as shown in Fig. 7 (Benghezal, 1989). The author used a CaO-rich clay, similar to the marl of the present study. These reddish samples belong to the phyllosilicate group (a), characterized by the chlorite (001) and three illite peaks. EFT's of $<700{ }^{\circ} \mathrm{C}$ can be deduced from Fig. 7, since chlorite is no longer stable above this temperature (Fig. 7). EFT calculations, deduced from the stability of chlorite as presented by Maritan (2004) and Maritan et al. (2006), give EFT's below $600{ }^{\circ} \mathrm{C}$. Both EFT's are consistent with the recorded $T_{\max }$. of samples $2004 / 7\left(582{ }^{\circ} \mathrm{C}\right)$ and $2006 / 3\left(633^{\circ} \mathrm{C}\right)$, but not with the $981^{\circ} \mathrm{C}$ of specimen $2006 / 1$.

\section{Conclusions}

$T_{\text {max., }}$, heating rate and soaking time recordings in the body of three pots during a bonfire firing agree well with published ethnographic or experimental data obtained with measurements of the gas temperature outside a pot. Maximum temperatures as high as $800-900{ }^{\circ} \mathrm{C}$ were reached in $7-22 \mathrm{~min}$ (heating rates $35-75-115^{\circ} \mathrm{C} / \mathrm{min}$ ). The range of the thermal variation within one pot during a single firing can be as high as $390^{\circ} \mathrm{C}$, and up to $220^{\circ} \mathrm{C}$ on a specific cross-section. The lowest temperature is not systematically recorded in the core of the object, as generally expected. Equivalent firing temperature (EFT) estimations diverge greatly from the measured $T_{\max }$. This demonstrates once more that mineral reactions are governed not only by $\mathrm{fO}_{2}$ and temperature, but also by other parameters such as granulometry, heating rate and

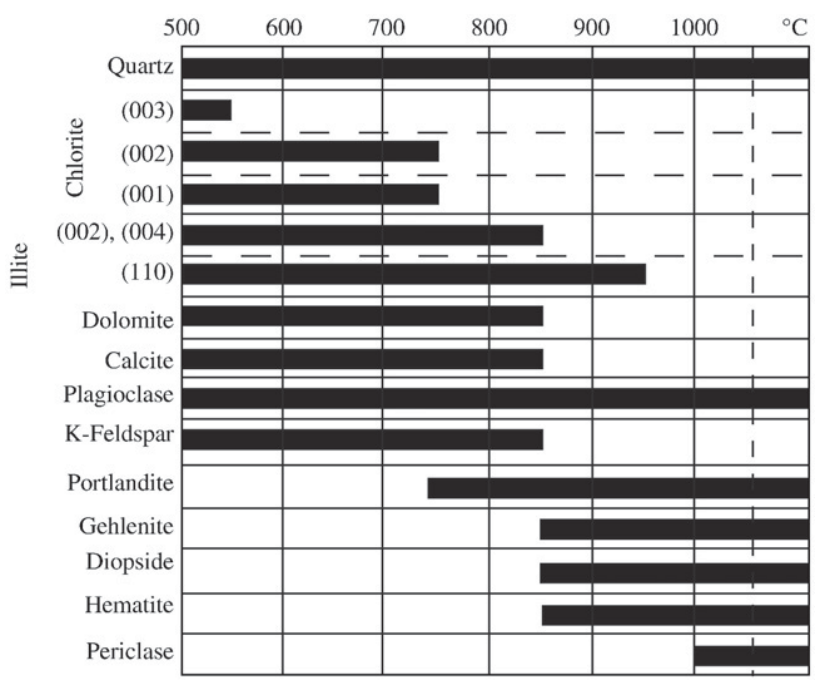

Fig. 7. Stability of minerals in a calcareous clay under oxidizing conditions (Benghezal 1989). Indexing of illite as $1 \mathrm{Md}$ polymorph. 
soaking time. Coarse grained calcite resists longer than fine grained, as shown by some experiments of Peters and Jenny (1973) where calcite disappeared under oxidizing conditions at $640{ }^{\circ} \mathrm{C}$ in the $<2 \mu \mathrm{m}$ fraction, and at $710{ }^{\circ} \mathrm{C}$ in the "total marl". According to these authors, slow heating rates of $1{ }^{\circ} \mathrm{C} / \mathrm{min}$ favour the dissociation of calcite, since it is no longer stable above $720^{\circ} \mathrm{C}$. Fast heating rates of $10^{\circ} \mathrm{C} / \mathrm{min}$ extend the stability of calcite up to $800^{\circ} \mathrm{C}$. Meyer et al. (1984) came to the same conclusions. Therefore, in the 2004, 2006 and 2008 experiments, calcite was stable due to: (1) coarse grained temper; (2) very fast heating rates; (3) short soaking time in the critical temperature interval; and (4) the mostly reducing atmosphere inside the pottery during the firing cycle.

All published experiments, used for EFT calculations, differ greatly in the composition of both raw materials and experimental devices, which easily explain the diverging and contradictory results (for a detailed discussion see Freudiger-Bonzon 2005, Appendix 7). Further, physico-chemical equilibria were neither reached in the experimental firings nor in the ancient, Neolithic firings. EFT determinations of bonfire fired pottery, as precise they may appear, can therefore only be a rough estimation.

\section{Acknowledgements}

The authors thank Prof. Dr. G. Galetti for the chemical analysis, N. Bruegger for the drawings, P. Gisler for his assistance in microphotography and J.-P. Bourqui as well as P. Dietsche for their help during the firing experiments. We are indebted to an anonymous reviewer and to the editor, whose comments improved the manuscript.

\section{References}

Basso, E., Binder, D. Messiga, B Riccardi, M.P. 2006. The Neolithic pottery of Abri Pendimoun (Castellar, France): a petro-archaeometric study. In: Maggetti, M. Messiga, B. (Eds.), Geomaterials in Cultural Heritage. Special Publication, 257. Geological Society, London, pp. 33-48.

Becker, D., 1996. Géologie de la région de Cornaux (Jura/Ne), et des marnières de Cornaux et Wallenried (USM), Unpublished Diploma Thesis, University of Fribourg.

Becker, D., 2003. Paléoécologie et paléoclimats de la Molasse du Jura (Oligo-Miocène): apport des Rhinocerotoidea (Mammalia) et des minéraux argileux. Geofocus, 9. Université de Fribourg, Institut de Géologie et Paléontologie.

Becker, D., Rössner, G.E., Picot, L., Berger, J.P., 2001. Early Miocene ruminants of Wallenried (USM, Aquitanian/Switzerland): sedimentology, biostratigraphy and paleoecology. Eclogae Geologicae Helvetiae 94, 547-564.

Benghezal, A., 1989. Groupes de référence des poteries gallo-romaines de Seeb (Suisse) et Oberwinterthur (Suisse): caractéristiques minéralogiques, chimiques et techniques. Unpublished Diploma Thesis, University of Fribourg.

Colton, H.S., 1951. Hopi pottery firing temperatures. Plateau 24, 73-76.

Fabbri, B., Gualtieri, S., Santoro, S., 2002. The importance of the firing atmosphere in the production of coarse ceramics with calcite and chamotte inclusions. In: Jerem, E., Biro, K. (Eds.), Archaeometry 98, Proceedings of the 31st Symposium, Budapest, April 26-May 3 1998: BAR International Series, 1043, pp. 191-195.

Freudiger-Bonzon, J., 2005. Archaeometrical study (petrography, mineralogy and chemistry) of Neolithic Ceramics from Arbon Bleiche 3 (Canton of Thurgau, Switzerland. Geofocus 11, Department of Geosciences, University of Fribourg.

Gibson, A., Wood, A., 1977. Prehistoric Pottery for the Archaeologist, 2nd ed. Leicester University Press, London and Washington.

Gosselain, O.P., 1992. Bonfire in the enquiries. Pottery firing temperatures in archaeology: what for? Journal of Archaeological Sciences 19, 243-259.

Heimann, R., 1976. Methoden zur Ermittlung der Original-Brenntemperatur von antiker Keramik. Informationsblätter zu Nachbarwissenschaften der Ur- und Frühgeschichte 7, 5,1-5,8.

Heimann, R., 1982. Firing technologies and their possible assessment by modern analytical methods. In: Olin, J.S., Franklin, J.D. (Eds.), Archaeological Ceramics. Smithsonian Institution, Washington D. C, pp. 89-96.

Heimann, R., 1989. Assessing the technology of ancient pottery: the use of ceramic phase diagrams. Archaeomaterials 3, 123-149.

Heimann, R., Franklin, U.M., 1980. Archaeo-thermometry: the assessment of firing temperatures of ancient ceramics. Journal of the International Institute for Conservation, Canadian Group 4, 23-45.

Heimann, R., Maggetti, M., Einfalt, H.C., 1980. Zum Verhalten des Eisens beim Brennen eines kalkhaltigen illitischen Tons unter reduzierender Bedingungen. Berichte der Deutschen Keramischen Gesellschaft 57, 145-152.

Irwin, G. J., 1977. The emergence of Mailu as a central place in the prehistory of coastal Papua. Ph. D. Thesis, Australian National University.

Kanimba, M., Bellomo, R.V., 1990. Methods of pottery construction and firing techniques observed in the village of Bukokoma II, Zaïre. In: Boaz, N.T. (Ed.),
Evolution of Environment and Hominidae in the African Western Rift Valley. Virginia Museum of Natural History, Martinsville, pp. 339-356.

Lange, B., Vejdelek, Z.J., 1980. Photometrische Analyse. Verlag Chemie, Altenberg.

Lauer, P.K., 1972. A neglected aspect of New Guinea pottery technology: firing. Pottery in Australia 11, 7-16.

Lauer, P.K., 1974. Pottery traditions in the d'Entrecasteaux islands of Papua. University of Queensland Occasional Papers in Anthropology, 3.

Laviano, R., Muntoni, I.M., 2006. Provenance and technology of Apulian Neolithic pottery. In: Maggetti, M. Messiga, B. (Eds.), Geomaterials in Cultural Heritage. : Special Publication, 257. Geological Society, London, pp. 49-62.

Letsch, J., Noll, W., 1983. Phase formation in several ceramic subsystems at $600{ }^{\circ} \mathrm{C}-$ $1000^{\circ} \mathrm{C}$ as a function of oxygen fugacity. Berichte der Deutschen Keramischen Gesellschaft 7, 259-267.

Livingstone Smith, A., 2001. Bonfire II: the return of pottery firing temperatures. Journal of Archaeological Science 28, 991-1003.

Maggetti, M., 1982. Phase analysis and its significance for technology and origin. In: Olin, J.S., Franklin, A.D. (Eds.), Archaeological Ceramics. Smithsonian Institution Press, Washington D. C., pp. 121-133.

Maggetti, M., 2009. Neolithic pottery from Switzerland: raw materials and manufacturing processes. In: Shortland, A.J., Freestone, I.C., Rehren, Th. (Eds.), From Mine to Microscope, Advances in the Study of Ancient Technology. Oxbow Books, Oxford, pp. 29-42.

Maniatis, Y., Simopoulos, A., Kostikas, A., Perdikatsis, V., 1983. Effect of reducing atmosphere on minerals and iron oxides developed in fired clays: the role of Ca. Journal of the American Ceramic Society 66, 773-781.

Maritan, L., 2004. Archaeometric study of Etruscan-Padan type pottery from the Veneto region: petrographic, mineralogical and geochemical-physical characterization. European Journal of Mineralogy 16, 297-307.

Maritan, L., Nodari, L., Mazzoli, C., Milano, A., Russo, U., 2006. Influence of firing conditions on ceramic products: experimental study on clay rich in organic matter. Applied Clay Science 31, 1-15.

Martineau, R., Pétrequin, P., 2000. La cuisson des poteries néolithiques de Chalain (Jura), approche expérimentale et analyse archéologique. In: Pétrequin, P.. Thiriot, J., Benoit, P. (Eds.), Arts du feu et productions artisanales. XXe Rencontres Internationales d'Archéologie et d'Histoire d'Antibes, Editions APDCA, Antibes, pp. 337-358.

Martineau, R., Walter-Simonet, A.V., Grobéty, B., Buatier, M., 2007. Clay resources and technical choices for Neolithic pottery (Chalain, Jura, France): chemical, mineralogical and grain-size analyses. Archaeometry 49, 23-52.

Meyer, Ch., Kaufmann, B., Keller, H.J., 1984. Das Mikrogefüge grobkeramischer Scherben. Beiträge zur Geologie der Schweiz. Geotechnische Serie, 63. Schweizerische Geotechnische Kommission, Zürich.

Miller, D., 1985. Artefacts as categories. A Study of Ceramic Variability in Central India. Cambridge University Press, Cambridge.

Mirti, P., 1998. On the use of colour coordinates to evaluate firing temperatures of ancient pottery. Archaeometry 40, 45-57.

Mpika, L., 1986. La Céramique Traditionelle des Kongo de la Région de Boko, XVIIIe-XXe Siècle. Mémoire de D.E.S., University Marien Ngouabi.

Nicholson, P.R., Patterson, H.L., 1989. Ceramic technology in the Upper Egypt: a study of pottery firing. World Archaeology 21, 71-86.

Nicklin, K., 1981. Ceramic pyrometry: two Ibibio examples. In: Howard, H., Morris, E.L. (Eds.), Production and Distribution: a Ceramic Viewpoint: BAR International Series, 120, pp. 347-359. Oxford.

Peters, Tj., Jenny, J.-.P., 1973. Mineralogische Untersuchungen über das Brennverhalten von Ziegeltonen. Beiträge zur Geologie der Schweiz. : Geotechnische Serie, 50. Schweizerische Geotechnische Kommission, Zürich.

Pinçon, B., 1984. La Céramique Teke de la Région de Zanaga (XIXème - XXème Siècle). Mémoire du Degré d'Études Supérieures, University of Marien Ngouabi.

Pradell, T., Molera, J., Garcia-Vallés, M., Vendrell-Saz, M., 1995. Study and characterization of ceramics fired under reducing conditions. In: Vendrell, M., Molera, J., Pradell, T., Garcia-Vallés, M. (Eds.), Studies on Ancient Ceramics. Generalidat de Catalunya, Barcelona, pp. 239-246.

Ramseyer, D., 1997. La construction d'une ferme néolithique comme il y a 5000 ans. Revue Chantiers 1, 53-58.

Rye, O.S., 1976. Keeping your temper under control: materials and the manufacture of Papuan pottery. Archaeology and Physical Anthropology in Oceania 11, 106-137.

Rye, O.S., 1981. Pottery Technology: Principles and Reconstruction. Taraxacum, Washington DC.

Seehy, J.J., 1988. Ceramic ecology and the clay/fuel ratio: modeling fuel consumption in Tlajinga 33, Teotihuacan, Mexico. In: Kolb, C.C. (Ed.), Ceramic Ecology Revisited, 1987: the Technology and Socio Economics of Pottery, Part I: BAR International Series, 436, pp. 199-226. Oxford.

Sestier, C., 2007. Étude du profil thermique d'une structure de combustion en meule (pitkiln): four ou foyer simple? In: Gheorgiu, D. (Ed.), Fire as an Instrument: the Archaeology of Pyrotechnologies: BAR International Series, 1619, pp. 25-31. Oxford.

Shepard, A.O., 1976. Ceramics for the Archaeologist, fifth ed. Carnegie Institution of Washington, Publication 609, Washington, D.C.

Shepard, A.O., 1977. Beginnings of ceramic industrialization: an example from Oaxaca Valley. Notes From a Ceramic Laboratory, 2. Carnegie Institution of Washington, Washington.

Tite, M.S., 1969. Determination of the firing temperature of ancient ceramics by measurement of thermal expansion: a reassessment. Archaeoemetry 11, 131-143.

Tite, M.S., 1995. Firing temperature determinations - how and why? KVHAA Konferenser 34, 37-42.

Tobert, N., 1984a. Ethnoarchaeology of pottery firing in Darfur, Sudan: implications for ceramic technology studies. Oxford Journal of Archaeology 3, 141-156. 
Tobert, N., 1984b. Potters of El-Fasher: one technique practiced by two ethnic groups In: Picton, J. (Ed.), Earthenware in Asia and Africa. Percival David Foundation, London, pp. 303-325.

Woods, A.J., 1984. Methods of pottery manufacture in the Kavango region of Namibia: two case studies. In: Picton, J. (Ed.), Earthenware in Asia and Africa. Percival David Foundation, London, pp. 219-237.
Wotzka, H.-P., 1991. Keramikbrand im offenen Feuer: vergleichende Analyse pyrometrischer Daten aus dem Töpferdorf Ikenge (Äquatorregion, Zaïre). In: Lüdtke, H., Vossen, R. (Eds.), Töpfereiforschung - archäologisch, ethnologisch, volkskundlich. Rudolf Habelt, Bonn, pp. 289-318. 